\title{
Analysis of pasture supplementation strategies by means of a mechanistic model of ruminal digestion and metabolism in the dairy cow
}

\author{
J. P. McNamara, ${ }^{* 1}$ M. J. Auldist, $†$ L. C. Marett, † P. J. Moate, $†$ and W. J. Wales $†$ \\ ${ }^{*}$ Department of Animal Sciences, Washington State University, Pullman 99164-6310 \\ †Agriculture Research Division, Department of Environment and Primary Industries, Ellinbank, VIC 3821, Australia
}

\begin{abstract}
Effective pasture supplementation is critical to the efficiency of resource management in milk production. We understand a great deal about ruminal and metabolic processes in dairy cattle that control efficiency but we need to improve our ability to predict effects of practical feeding strategies based on the basic biological processes of the cow. Therefore, a large-scale pasture supplementation study was used to explore the details of both practical management and the underlying biological principles and processes involved. This included a multiple lactation study coupled with shorter-term experiments that tested the type and rate of supplementation. Basal supplementation strategies were (1) pasture allowance $[14 \mathrm{~kg}$ of dry matter $(\mathrm{DM}) / \mathrm{d}$ per cow] supplemented with milled barley grain fed twice daily in the milking parlor and pasture silage provided in the paddock; the ratio of grain:forage fed as supplement was 0.75:0.25 (control; DM basis); (2) the same pasture allowance plus the same amounts of milled barley grain and pasture silage, but the supplements were mixed and chopped before being fed immediately after each milking; and (3) the same pasture allowance and offered a partial mixed ration comprising barley (25\%) and corn grain ( $30 \%$ of DM), corn silage ( $20 \%$ of DM), and alfalfa hay ( $25 \%$ of DM) after each milking. In late lactation ( $227 \mathrm{~d}$ in milk), a short-term experiment was done feeding the same pasture allowances but with the 3 supplements offered at $6,8,10$, and $12 \mathrm{~kg}$ of DM/d for an 11-d measurement period following adaptation to the diet to each of the 3 long-term supplementation groups. Production responses were recorded and ruminal volatile fatty acids (VFA) and $\mathrm{pH}$ were measured in a subset of animals. Model descriptions of yields of milk and milk constituents as well as mean concentrations of ruminal fluid VFA and ruminal fluid $\mathrm{pH}$ were compared with measured values resulting when dairy cows were fed 12 different pasture-based diets with different levels
\end{abstract}

Received February 10, 2016.

Accepted October 1, 2016.

${ }^{1}$ Corresponding author: mcnamara@wsu.edu and types of dietary supplement. Inputs into the model were measured dry matter intake and feed composition on the 12 combined treatments as well as initial body weight and composition. The model described milk and milk component production within 1 standard deviation of the treatment means (less than $5 \%$ of the mean as measured in the root mean square error). The simulated proportions of ruminal acetate, propionate, and butyrate were consistent with observed effects of supplemental treatments and rate of supplementation; however, the error analysis showed room for improvement. The model described, to a general extent, the changes in ruminal $\mathrm{pH}$; however, this investigation showed that the equations that describe ruminal $\mathrm{pH}$ need to be improved or modified. These results show that the fundamental knowledge of ruminal and organ metabolism in this mechanistic model is sufficient to describe the qualitative responses to complicated dietary strategies, but our quantitative understanding of the parameters involved such as degradation and absorption kinetics and ruminal $\mathrm{pH}$ still demands more specific research.

Key words: pasture, supplementation, digestion, mechanistic modeling

\section{INTRODUCTION}

In many parts of the world, pasture provides the basic nutrient supply for lactating dairy cattle. Although much is understood about grazing management, a wide variety of supplemental systems are available, and producers must account for the variability, availability, and cost of feedstuffs. Production increases in response to supplements in pasture-fed cows are well established (Walker et al., 2001; Leddin et al., 2009), but often the response is curvilinear, with poorer responses being observed as the amount of grain increases (Stockdale et al., 1987; Walker et al., 2001). The pasture amount, quality, and stage of lactation all affect milk production responses to supplemental grain (Walker et al., 2001; Beever and Doyle, 2007). Feeding high amounts of cereal supplements in the parlor can increase variations in ruminal fluid $\mathrm{pH}$, impair NDF digestion, and lead to 
less pasture being consumed (Mould et al., 1983; Stockdale, 2000; Wales and Doyle, 2003; Leddin et al., 2009).

Research models are used in systems and quantitative biology approaches to describe the complex digestive and metabolic processes in the dairy cow (Baldwin, 1995; Hanigan et al., 2009; McNamara and Shields, 2013; Gregorini et al., 2014). One is the Molly model from Baldwin (1995) that has been developed over 4 decades and is in use in several research programs worldwide (Hanigan et al., 2009, 2013; Gregorini et al., 2013, 2014; McNamara, 2015). The model describes digestive processes and organ metabolism in lactating dairy cattle and is useful in describing the underlying biological processes that control practical production responses (McNamara and Baldwin, 2000; Hanigan et al., 2006, 2013; Gregorini et al., 2013, 2014; McNamara and Shields, 2013). Although the model has elements that describe feeding of high forage and highly soluble forage, it has not been specifically studied to determine how well it would describe more complicated pasture feeding and supplementation regimens, and more importantly, where it does not describe these situations well. In particular, it is challenging to describe ruminal VFA metabolism and resultant metabolic pathway fluxes as a result of complex feeding strategies (Hanigan et al., 2013). Research models such as Molly are most useful when they point out remaining gaps in knowledge and are continually improved. Such challenges are valuable in improving our quantitative understanding of biological control mechanisms in a wide variety of feeding situations, which can improve our flexibility in such feeding systems.

Therefore, we used a large-scale pasture supplementation study that was designed in part to challenge and improve existing research and applied models to provide a modeling challenge and analysis. Therefore, in this modeling experiment, the objective was to use an existing well-validated mechanistic, dynamic model of metabolism in the dairy cow (Baldwin, 1995; and updates: Hanigan et al., 2009) to determine how well the model describes key aspects of digestion and metabolism in the dairy cows. The specific hypothesis tested was that the model can describe the response to increasing the amounts of grain and forage supplement fed to cows grazing a low allowance of pasture in late lactation, including the pattern of rumen fermentation. Instances in which the model could not describe observations well would point to specific gaps in knowledge that could be filled with further experiments.

\section{MATERIALS AND METHODS}

The full experimental description and results of the animal trial are published in Auldist et al. (2013). In brief, to conduct the full-lactation experiment, 216 Holstein Friesian cows were allotted to 1 of 3 groups of 72 cows. Cows in the 3 groups grazed separately but on similar adjacent paddocks over a 34-wk period. For the first 17 wk, partial mixed rations (PMR) were offered once daily, following the morning milk and pasture offered once daily following the afternoon milking. Diets were (1) control (CONT): grazed perennial ryegrass pasture supplemented with milled barley grain fed twice daily in the milking parlor and pasture silage offered once daily in the paddock. The ratio of barley:silage was 0.75:0.25 (DM basis); (2) the same pasture and allotment supplemented with the same amounts of milled barley grain and pasture silage, but presented as a mixed ration on a feed pad after each milking (PMR1); and (3) the same pasture and allotment, supplemented with a mixed ration of barley grain, alfalfa hay, corn silage and corn grain (PMR2). All supplements were formulated to be isoenergetic and all feeding strategies provided the same ME intake and grain:forage ratio.

For the short-term supplementation study, at a mean of 227 DIM (range 176 to $256 \mathrm{~d}$ ), within each of the 3 long-term dietary treatment groups of 72 cows, cows were randomly allotted to 2 groups of 36 cows. Animals within each of these 2 groups were then randomly allotted to 4 groups of 9 cows, which were fed the trial supplements (CONT, PMR1, PMR2). The supplements were fed at 4 rates of feeding: $6,8,10$, and $12 \mathrm{~kg} / \mathrm{d}$ of DM. Thus, CONT animals received the CONT supplement at 4 rates and the PMR1 and PMR2 groups their respective supplement at each of the 4 rates. The 25 -d experiment comprised a 14-d adaptation period and an 11-d measurement period. Pasture allowance for all cows was approximately $14 \mathrm{~kg}(\mathrm{DM}) / \mathrm{cow}$ per day, and pasture intake ranged between 7.9 and $9.5 \mathrm{~kg} \mathrm{DM} /$ cow per day. Table 1 contains the production characteristics of the animals immediately before the short-term supplementation study and the parameter values of the model set to represent those conditions. Tables 2 and 3 list the amount of pasture and feed supplements consumed and the nutritive characteristics of the diets fed.

\section{Simulation Modeling Analysis}

Molly is a deterministic, mechanistic, dynamic model representing the digestion, metabolism, and production of a dairy cow (Baldwin, 1995). The rumen model is constructed at an aggregated biochemical pathway level to describe degradation and fermentation of feedstuffs and substrates (soluble carbohydrate, starch, cellulose, hemicellulose, organic acids, proteins) in the rumen, microbial growth, digestion, and absorption of nutrients. In the animal model, the major pathways 
Table 1. Starting conditions of animals measured in study and the starting model parameters for milk, milk fat, and milk protein ${ }^{1}$

\begin{tabular}{|c|c|c|c|c|c|c|c|c|c|c|}
\hline Treatment $^{2}$ & DIM & $\begin{array}{c}\text { Age, } \\
\text { yr }\end{array}$ & $\begin{array}{c}\text { BW, } \\
\text { kg }\end{array}$ & $\begin{array}{l}\text { Milk, } \\
\text { kg }\end{array}$ & MamCellsPart & $\begin{array}{l}\text { Protein, } \\
\text { kg }\end{array}$ & $\begin{array}{l}\text { Vmax } \\
\mathrm{AaPm}\end{array}$ & $\begin{array}{l}\text { Fat, } \\
\text { kg }\end{array}$ & $\begin{array}{l}\text { Vmax } \\
\text { AcTm }\end{array}$ & $\begin{array}{l}\text { Vmax } \\
\text { FaTm }\end{array}$ \\
\hline $\mathrm{CONT}$ & 227 & 4.5 & 587 & 5,338 & 620 & 168 & 0.00179 & 239 & 0.0084 & 0.0012 \\
\hline PMR1 & 229 & 4.2 & 603 & 5,239 & 577 & 166 & 0.00183 & 224 & 0.00801 & 0.00114 \\
\hline SD & 17.6 & 1.60 & 60.7 & 745.9 & 84.4 & 23.3 & 0.00011 & 41.2 & 0.00098 & 0.00014 \\
\hline
\end{tabular}

${ }^{1}$ Inputs into the Molly model were (experimental variable = Molly variable name) DIM = DIM; BW = iBWF, and the observed milk, milk fat and milk protein were used to set the MamCellsPart (milk production starting point); and the Vmax parameters for AcTm and FaTm (acetate to milk fat and fatty acids to milk fat) and AaPm (amino acids to milk protein) were adjusted to match the observed initial experimental values. MamCellsPart was calculated as a direct function of the observed amount of milk production compared with the default value of this parameter in the model, 25.3 MamCellsPart per $\mathrm{kg} / \mathrm{d}$ milk.

${ }^{2} \mathrm{CONT}=$ grazed perennial ryegrass pasture supplemented with milled barley grain fed twice daily in the milking parlor and pasture silage offered once daily in the paddock. The ratio of barley:silage was 0.75:0.25 (DM basis); PMR1 = same pasture and allotment supplemented with the same amounts of milled barley grain and pasture silage, but presented as a mixed ration on a feed pad after each milking; PMR2 = same pasture and allotment, supplemented with a mixed ration of barley grain, alfalfa hay, corn silage, and corn grain.

of protein synthesis and degradation; lipid synthesis and degradation; amino acid, fatty acid, and glucose oxidation to generate ATP; gluconeogenesis from amino acids and propionate; and production of milk, milk fat, milk protein, and milk lactose are explicitly described at the aggregated pathway level (Baldwin et al., 1987a,b,c; Baldwin, 1995; Hanigan et al., 2009). Since the original publications of the model, parameterfitting meta-analyses have been used to improve the parameter values and improve the mammary growth and metabolism equations, and much of the computer coding has been updated, but the basic structure of the model remains the same (Hanigan et al., 2006, 2007, 2009).
Inputs of feed in the model simulations included the measured intakes of total DM, CP, cellulose, hemicellulose, and lignin, lipid, starch, soluble carbohydrates, organic acids, pectin, and soluble and insoluble ash as listed in Tables 2 and 3. Pasture intake was measured with field sampling of grazing amount and chemical composition (Auldist et al., 2013) and supplement DMI was measured directly (Auldist et al., 2013). Insoluble and soluble protein was determined from actual intakes of $\mathrm{CP}$ and Cornell Net Carbohydrate and Protein System (CNCPS; https://blogs.cornell.edu/cncps/purchase/) feed composition of rumen soluble and insoluble protein. Inputs of initial animal characteristics, including BW, BCS (used to calculate initial body fat), and

Table 2. Pasture and supplement intakes (in $\mathrm{kg}$ of $\mathrm{DMI} / \mathrm{d}$ or $\mathrm{MJ} /$ cow per $\mathrm{d}$ ) for cows in a short-term supplementation trial in late lactation

\begin{tabular}{|c|c|c|c|c|c|c|c|c|c|c|c|}
\hline Treatment $^{1}$ & $\begin{array}{l}\text { Supplement } \\
\text { offered, } \mathrm{kg} / \mathrm{d}\end{array}$ & \multicolumn{2}{|c|}{ Pasture } & \multicolumn{2}{|c|}{ Supplement } & \multicolumn{4}{|c|}{ Total intake } & $\mathrm{PU}^{2}$ & $\mathrm{SR}^{3}$ \\
\hline \multirow[t]{3}{*}{ CONT } & 6 & 9.5 & 113 & 5.9 & 76 & 15.4 & 189 & 6.98 & 3.13 & 65.5 & - \\
\hline & 10 & 8.6 & 108 & 9.8 & 127 & 18.4 & 235 & 7.18 & 3.71 & 61.8 & 0.37 \\
\hline & 12 & 8.2 & 100 & 11.8 & 152 & 19.9 & 253 & 7.81 & 3.51 & 59.7 & 0.19 \\
\hline \multirow[t]{2}{*}{ PMR1 } & 6 & 9.3 & 111 & 5.6 & 73 & 14.9 & 184 & 6.55 & 3.10 & 64.6 & - \\
\hline & 12 & 7.9 & 91 & 11.2 & 145 & 19.1 & 237 & 7.65 & 3.28 & 53.5 & 0.65 \\
\hline \multirow[t]{4}{*}{ PMR2 } & 6 & 9.5 & 118 & 6.4 & 79 & 15.8 & 197 & 6.59 & 3.40 & 63.9 & - \\
\hline & 8 & 9.4 & 113 & 8.2 & 102 & 17.6 & 214 & 7.38 & 3.59 & 63.5 & 0.04 \\
\hline & 10 & 8.5 & 114 & 10.2 & 127 & 19.2 & 241 & 7.47 & 3.88 & 60.4 & 0.23 \\
\hline & 12 & 9.3 & 115 & 12.3 & 153 & 21.6 & 268 & 8.30 & 4.11 & 62.1 & -0.19 \\
\hline$P$-value: treatment & & 0.548 & 0.156 & 0.002 & 0.009 & 0.089 & 0.042 & 0.820 & 0.110 & 0.733 & - \\
\hline$P$-value: rate & & 0.006 & 0.041 & $<0.001$ & $<0.001$ & $<0.001$ & $<0.001$ & $<0.001$ & 0.054 & 0.006 & - \\
\hline
\end{tabular}

${ }^{1}$ CONT $=$ grazed perennial ryegrass pasture supplemented with milled barley grain fed twice daily in the milking parlor and pasture silage offered once daily in the paddock. The ratio of barley:silage was 0.75:0.25 (DM basis); PMR1 = same pasture and allotment supplemented with the same amounts of milled barley grain and pasture silage, but presented as a mixed ration on a feed pad after each milking; PMR2 = same pasture and allotment, supplemented with a mixed ration of barley grain, alfalfa hay, corn silage, and corn grain.

${ }^{2} \mathrm{PU}=$ (pasture consumed $/$ pasture allowance $) \times 100$.

${ }^{3} \mathrm{SR}=$ reduction in pasture DMI/increase in supplement DMI.

${ }^{4}$ Least significant difference $(P<0.05)$ for the comparison between treatments within levels of feeding. 
measured starting milk fat and protein content, were all set as inputs from experimental data. The starting BW and BCS inputs were the mean values for the lactation treatment and supplement group means. The point of the study was not to try to demonstrate that the model predicts perfectly a response to a feed change, as would be the case for a field model, but to use the research model to ask questions about the underlying biology in a complicated feeding study.

The average starting values for each dietary treatment group of cows was used to set the model parameters for milk (MamCellsPart), milk fat (VFaTm and VAcTm), and milk protein (VAaPm) for starting the model analysis of the supplement period (Table 1). The parameter MamCellsPart was calculated as a direct function of the observed amount of milk production compared with the default value of this parameter in the model, 25.3 MamCellsPart per kg/d milk; and the maximal velocities were calculated as the similar ratio of the default. Outputs included amount of milk, milk components and changes in body fat and protein and rumen volatile fatty acids and $\mathrm{pH}$.

The rumen sub-model was constructed to simulate the fermentation of soluble carbohydrate, starch, hemicellulose, and cellulose to acetate, propionate, and butyrate, using a meta-analytic data set (Murphy et al., 1982). Three different VFA stoichiometric patterns constructs were developed: FORSET, VFA pattern from high-forage diets ( $60-70 \%$ forage); MIXSET, VFA pattern on mixed forage:concentrate ratios (40-60\% forage:concentrate) and CONSET, VFA pattern on high-concentrate diets (60-70\% concentrate). The descriptions of VFA flux were updated to fit recent data sets (Hanigan et al., 2009). Thus, the assumed VFA pattern must be set based on the type of diet being stimulated, with most dairy diets being of the mixed variety. This modeling analysis provides an excellent challenge as it involves a range of animals in different stages of lactation and a range of diet types differing in amount of grain and forage to grain ratio.

\section{Experimental Design and Statistical Analysis}

The feeding study was analyzed as a randomized complete block with parity as block and with repeated measures in time; the full analysis is available in Auldist et al. (2013) and pertinent results provided in the tables and figures. For the modeling analysis, inputs into the model were the actual daily DMI and chemical composition and starting BW and BCS and DIM of the

Table 3. Feed composition (\% of DM) as measured and as input into the Molly model ${ }^{1}$

\begin{tabular}{|c|c|c|c|c|c|c|c|c|c|c|}
\hline $\begin{array}{l}\text { Lactation }^{2} \\
\text { treatment }^{2}\end{array}$ & $\begin{array}{l}\text { Replicate } \\
\text { group }\end{array}$ & $\begin{array}{l}\text { Supplementation } \\
\text { rate, } \mathrm{kg} / \mathrm{d}\end{array}$ & DM & $\mathrm{CP}$ & Fat & Starch & NDF & $\mathrm{ADF}$ & Lignin & Ash \\
\hline \multirow[t]{8}{*}{ CONT } & 1 & 1 & 90 & 18.4 & 7.2 & 15.8 & 46.0 & 23.7 & 3.3 & 8.4 \\
\hline & 2 & 1 & 90 & 22.2 & 7.6 & 15.4 & 44.8 & 21.9 & 2.6 & 8.9 \\
\hline & 1 & 2 & 90 & 18.5 & 6.8 & 18.2 & 43.0 & 21.5 & 2.5 & 7.9 \\
\hline & 2 & 2 & 90 & 19.3 & 7.8 & 18.2 & 42.4 & 21.3 & 2.7 & 8.3 \\
\hline & 1 & 3 & 90 & 19.7 & 6.7 & 20.6 & 38.5 & 20.9 & 2.7 & 8.3 \\
\hline & 2 & 3 & 90 & 20.8 & 7.0 & 21.7 & 39.4 & 19.3 & 3.5 & 7.5 \\
\hline & 1 & 4 & 90 & 17.9 & 5.7 & 23.4 & 38.7 & 19.6 & 2.8 & 7.6 \\
\hline & 2 & 4 & 90 & 17.4 & 7.1 & 23.2 & 39.3 & 19.5 & 2.5 & 9.9 \\
\hline \multirow[t]{8}{*}{ PMR1 } & 1 & 1 & 90 & 21.3 & 7.1 & 15.5 & 43.7 & 23.8 & 4.1 & 9.0 \\
\hline & 2 & 1 & 90 & 21.6 & 8.1 & 15.1 & 42.4 & 22.8 & 4.4 & 9.0 \\
\hline & 1 & 2 & 90 & 18.5 & 7.7 & 19.0 & 41.1 & 21.7 & 3.8 & 8.7 \\
\hline & 2 & 2 & 90 & 19.8 & 7.8 & 17.6 & 42.2 & 22.4 & 3.7 & 8.6 \\
\hline & 1 & 3 & 90 & 14.3 & 7.5 & 20.8 & 39.4 & 22.0 & 4.0 & 8.6 \\
\hline & 2 & 3 & 90 & 20.1 & 5.5 & 19.8 & 42.5 & 21.7 & 4.0 & 7.2 \\
\hline & 1 & 4 & 90 & 18.8 & 6.3 & 24.7 & 37.5 & 19.5 & 3.6 & 8.0 \\
\hline & 2 & 4 & 90 & 17.7 & 5.4 & 22.5 & 40.0 & 21.4 & 3.1 & 7.0 \\
\hline \multirow[t]{8}{*}{ PMR2 } & 1 & 1 & 90 & 22.4 & 8.2 & 15.7 & 41.4 & 22.3 & 3.5 & 9.7 \\
\hline & 2 & 1 & 90 & 21.7 & 7.1 & 14.7 & 42.5 & 24.2 & 4.2 & 9.3 \\
\hline & 1 & 2 & 90 & 21.5 & 5.7 & 17.8 & 42.1 & 23.8 & 4.0 & 7.9 \\
\hline & 2 & 2 & 90 & 20.5 & 6.0 & 17.4 & 42.9 & 23.4 & 4.1 & 7.7 \\
\hline & 1 & 3 & 90 & 20.8 & 6.0 & 20.1 & 40.9 & 22.7 & 4.3 & 7.4 \\
\hline & 2 & 3 & 90 & 21.0 & 6.5 & 20.2 & 38.1 & 21.0 & 4.1 & 7.9 \\
\hline & 1 & 4 & 90 & 20.7 & 5.6 & 21.5 & 39.6 & 22.4 & 4.5 & 6.6 \\
\hline & 2 & 4 & 90 & 18.9 & 7.1 & 21.3 & 38.4 & 21.9 & 4.1 & 8.2 \\
\hline
\end{tabular}

${ }^{1}$ The observed intakes for each individual cow were inputs (in kg of DMI/d at the listed DM percentages) into the Molly model and the measured variable names are the same as model variable names.

${ }^{2} \mathrm{CONT}=$ grazed perennial ryegrass pasture supplemented with milled barley grain fed twice daily in the milking parlor and pasture silage offered once daily in the paddock. The ratio of barley:silage was 0.75:0.25 (DM basis); PMR1 = same pasture and allotment supplemented with the same amounts of milled barley grain and pasture silage, but presented as a mixed ration on a feed pad after each milking; PMR2 = same pasture and allotment, supplemented with a mixed ration of barley grain, alfalfa hay, corn silage, and corn grain. 
observed animals. Two analyses were done, one on the means of the 24 dietary combinations as described in Table 1, and one using the individual animal observations. As animals were fed as feeding groups of 9, the actual DMI per animal were the same as for the means analysis, but the individual animal inputs for DIM, BCS, and BW were used and outputs compared with individual animal outputs. The model was considered qualitatively in agreement (for behavior and sensitivity of response) if simulated outputs were within $1 \mathrm{SD}$ of the observed means. The modeling study was then further analyzed by calculating root mean square prediction error (RMSPE; Roseler et al., 1997), which measures the sum of the mean bias [(actual, A - predicted, P)], the line bias $\left[\mathrm{S}_{\mathrm{P}}{ }^{2}(1-\mathrm{b})^{2}\right]$, and the random variation around the regression line $\left[\mathrm{S}_{\mathrm{A}}{ }^{2}\left(1-\mathrm{r}^{2}\right)\right]$. For example, for milk production, $\mathrm{A}=$ actual milk production, $\mathrm{P}=$ predicted milk production, $\mathrm{S}_{\mathrm{P}}{ }^{2}$ is the variance of the predicted milk production, $\mathrm{S}_{\mathrm{A}}{ }^{2}$ is the variance of the actual milk production, $\mathrm{b}$ is the slope of the regression of $\mathrm{A}$ on $\mathrm{P}$, and $\mathrm{r}$ is the correlation coefficient of $\mathrm{A}$ and $\mathrm{P}$. The comparisons of predicted and observed values were calculated directly on the data using the statistical functions of Excel (Microsoft Corp., Redmond, WA).

\section{RESULTS AND DISCUSSION}

\section{Observed Dietary Inputs and Milk Component Production Outputs}

The starting animal conditions are shown in Table 1 and the dietary intake characteristics in Tables 2 and 3. Full results of the feeding trial are in Auldist et al. (2013). Briefly, supplementation clearly increased $(P<$ 0.01) intake of all dietary nutrients, closely in line with the planned supplementation rate. The intake of the PMR1 supplement was less $(P<0.002)$ than that of either CONT or PMR2. In all cases, supplementation decreased pasture intake $(P<0.006)$ but increased overall intake as stated above, with no differences between the supplementation strategy groups. Increasing supplementation of any of the 3 supplements increased $(P<0.05)$ milk yield (Figure 1$)$ quadratically. Milk yield was slightly higher in the CONT group at lower supplement rates but equal among groups at higher supplement rates. Milk fat percentage decreased $(P$ $<0.05$, Figure 2) with supplement in the CONT and PMR1 groups but was maintained in the PMR2 group to provide the greatest milk fat yield at higher supplementation rates. Milk protein percent was not affected by supplementation (Figure 3) but milk protein yield was increased, with the greatest increase in the PMR2 group, as expected with the higher ME and protein intake.
The total ruminal concentration of VFA increased with increasing supplementation from 6 to $8 \mathrm{~kg} / \mathrm{d}$ and reached a plateau, as would be expected; however, these differences approached significance only at $P$ $=0.064$. We detected no difference in ruminal VFA between supplementation strategy groups. As more of the grain supplement was fed, the ratio of (acetate + butyrate):propionate gradually decreased as well, with the highest supplementation rate having the lowest ratio and the effect being more pronounced on the PMR1 and PMR2 strategies.

Ruminal $\mathrm{pH}$ declined $(P<0.028)$, on average, with increasing supplementation, as expected, with no difference between supplementation strategy groups. The minimum $\mathrm{pH}$ also declined with increasing supplementation, consistent with the increased VFA concentrations. These data in particular, as stated before, provide a serious challenge to any nutritional model's ability to describe the rumen environment.

\section{Results of the Modeling Analysis}

The data gathered in this experiment were used to conduct a model challenge using the data from this short-term intensive supplementation experiment to ask how well Molly could describe such responses and,

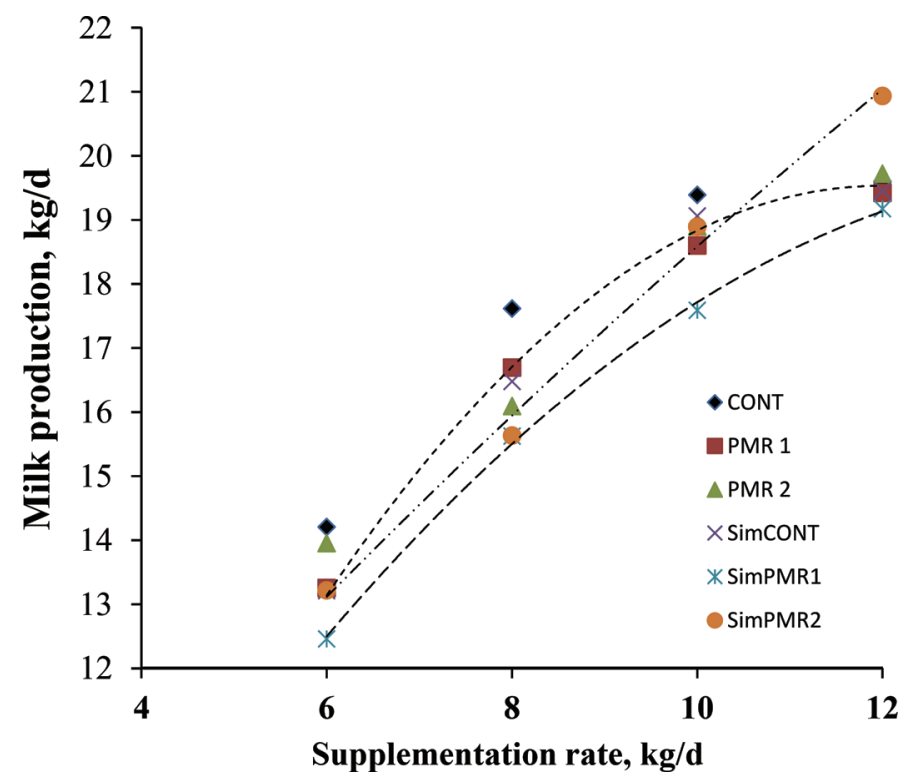

Figure 1. Observed and simulated (Sim) milk production $(\mathrm{kg} / \mathrm{d})$ in an 11-d pasture supplementation study. Animals were from 3 longterm supplementation treatments followed by an 11-d period of 6,8 , 10 , and $12 \mathrm{~kg}$ of that supplement per day. CONT (control) $=$ pasture allowance plus a simple supplement (quadratic fit); PMR1 = pasture allowance plus a mixed supplement; and PMR2 = pasture allowance plus a supplement balanced for protein and energy. SimCONT $=$ short-dashed line; SimPMR1 = long-dashed line; SimPMR2 = dashed dotted line. Color version available online. 
more importantly, where it fails to describe responses as precisely as needed.

From the model's ability to predict, we can increase confidence in our knowledge, and where it fails, we are directed clearly to the next experiments to conduct. The production and ruminal concentrations of VFA are functions of the total amounts of cellulose, hemicellulose, starch, and soluble carbohydrates as well as the fractional breakdown rates of cellulose and hemicellulose, and the uptake of VFA from the rumen (Baldwin et al., 1987a,b; Baldwin, 1995). Changes in these elements have been made recently so that the model fits to available data sets on a wide range of feed intakes and compositions (Hanigan et al., 2006, 2013; Gregorini et al., 2013, 2014) but it has not been specifically studied to determine how well it would describe more complicated pasture feeding and supplementation regimens. The present study was conducted to determine where the model could describe the supplementation strategies and where further research was still required.

The model was able to describe milk production and response to supplementation reasonably well. The total bias for milk was $0.56 \mathrm{~kg} / \mathrm{d}$ (only $3.3 \%$ of the mean milk production), partitioned to $68 \%$ mean bias, $7 \%$ line bias, and $24 \%$ random bias (Figure 4 ). The mean bias indicates that overall the model did well to describe dietary responses within 1 SD of the mean. The low line bias indicates good model structure in relation to control of milk synthesis, which has been routinely demonstrated for Molly (Baldwin, 1995; McNamara and Baldwin, 2000; Hanigan et al., 2006, 2007, 2009, 2013). The reasonable match between observed and simulated responses to increasing intake highlights the sound scientific structure of the model; however, there are clearly gaps in our knowledge that restrict the closeness of the mean fit in this study.

The model failed to describe the milk response to the highest rate of supplementation of the mixed supplement (PMR1), such that the model predicted milk production to continue to increase in response to increasing amount of supplement, whereas, in reality, milk production plateaued at the highest level of supplementation. This indicates that there are one or more errors in the model in the contributing processes of nutrient supply to the mammary gland. Because many cows in the world produce more milk than those in this experiment, we hesitate to interpret this to mean that the model has too much capacity, but it clearly failed here to limit the response. This is a strict test and demonstrates that our quantitative understanding as embodied in the model cannot yet describe the subtle changes in digestion and tissue metabolism at high rates of supplementation and moderate milk production.

The response to supplementation of milk fat yield as described by the model was reasonable (Figures 2 and 5). Clearly, supplementation increased milk fat yield

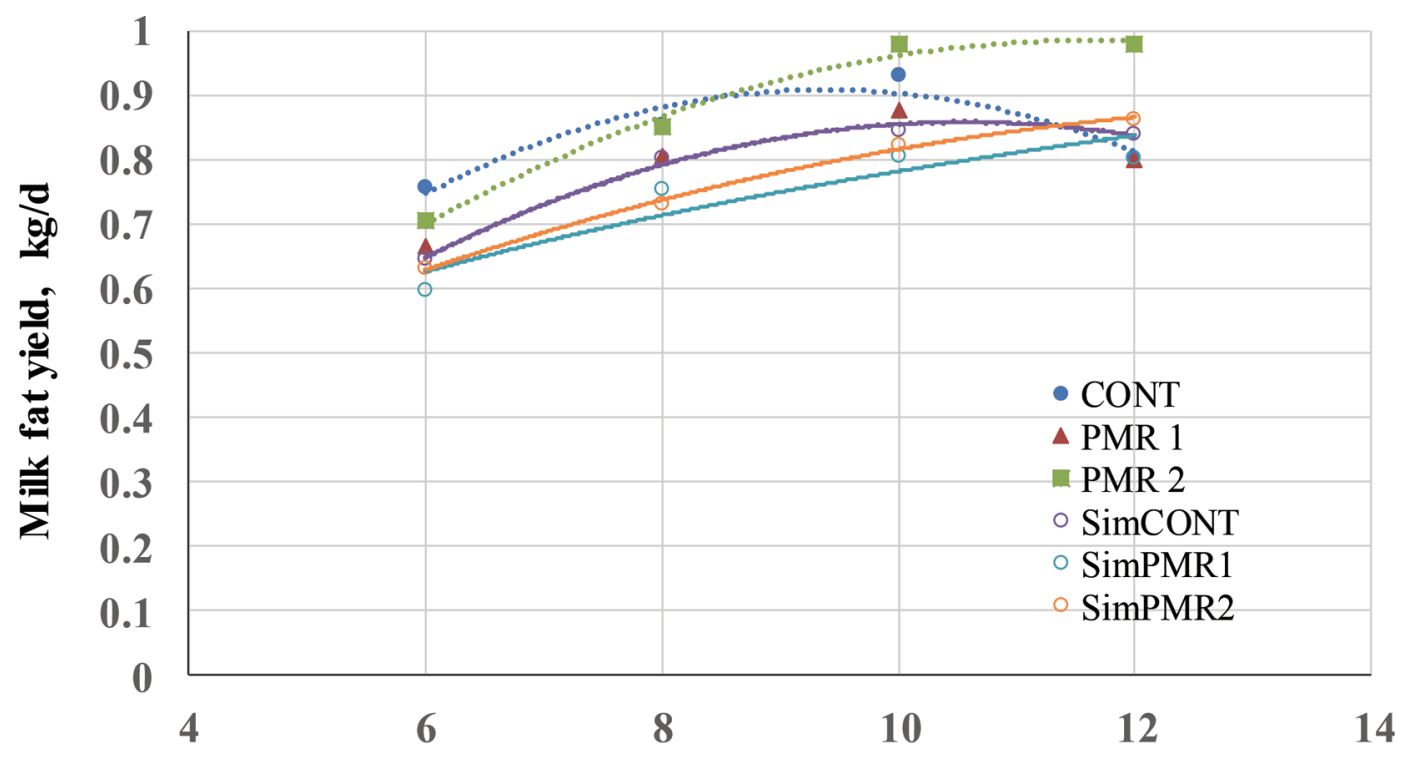

Supplementation Amount, kg/d

Figure 2. Observed and simulated (Sim) milk fat yield in an 11-d pasture supplementation study. Animals were from 3 long-term supplementation treatments followed by an 11-d period of $6,8,10$, and $12 \mathrm{~kg}$ of that supplement per day. CONT (control) = pasture allowance plus a simple supplement (quadratic fit); PMR1 = pasture allowance plus a mixed supplement; and PMR2 = pasture allowance plus a supplement balanced for protein and energy. Color version available online. 


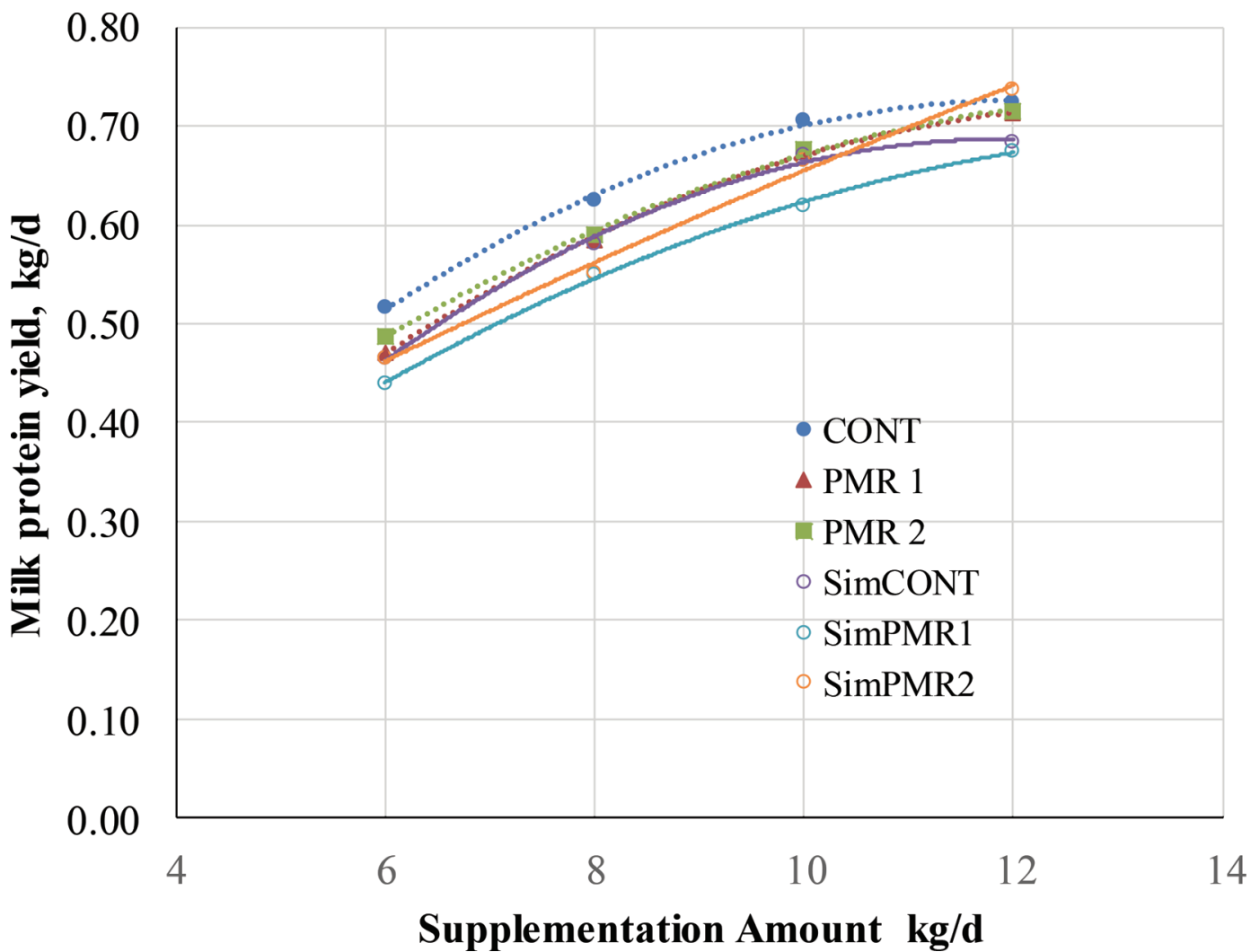

Figure 3. Observed and simulated (Sim) milk protein yield in an 11-d pasture supplementation study. Animals were from 3 long-term supplementation treatments followed by an 11-d period of $6,8,10$, and $12 \mathrm{~kg}$ of that supplement per day. CONT (control) $=$ pasture allowance plus a simple supplement (quadratic fit); PMR1 = pasture allowance plus a mixed supplement; and PMR2 = pasture allowance plus a supplement balanced for protein and energy. Color version available online.

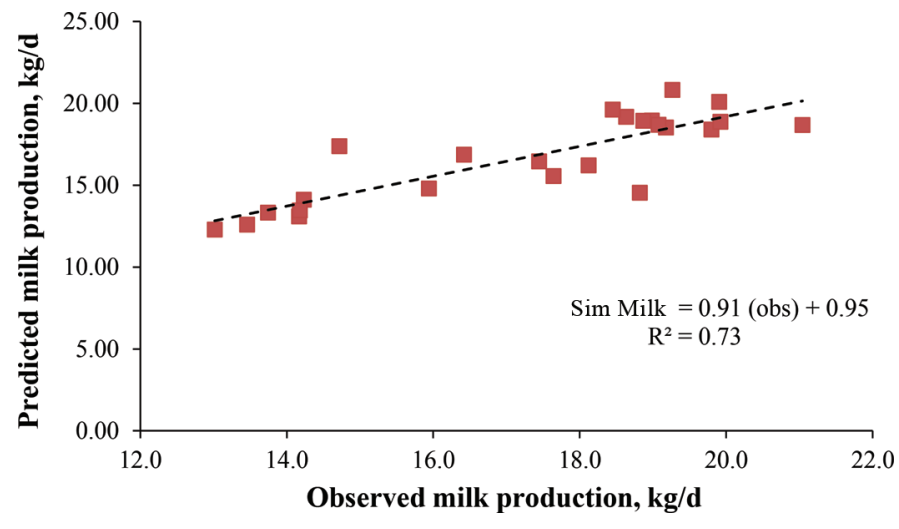

Figure 4. Regression comparison of simulated (Sim) and observed (obs) milk production for $11 \mathrm{~d}$ of a short-term pasture supplementation study. Animals were from 3 long-term supplementation treatments followed by a 12 -d period of either $6,8,10$ and $12 \mathrm{~kg}$ of that supplement per day: Control $=$ pasture allowance plus a simple supplement; PMR1 = pasture allowance plus a mixed supplement; and PMR2 = pasture allowance plus a supplement balanced for protein and energy. Color version available online. in a linear fashion, and the model was able to capture that quite well. As the initial parameters for the model simulation were set to the values of the animals at the start of the trial, the majority of the error was in the mean bias and this was about $9 \%$ of observed, indicating the model was over-predicting milk fat to a certain degree. However, the response to supplementation was reasonable. The total bias in the root mean square prediction error was $0.075 \mathrm{~kg} / \mathrm{d}$ or $9.0 \%$ of the observed mean and, of the total bias, the mean bias was $99.03 \%$, the line (slope) bias was $0.025 \%$, and the random bias was $0.94 \%$. This suggests that the model is structured to respond reasonably well to increases in feed supplementation in predicting total fat yield. The ability to describe responses to amount and type of diet for milk fat point to the ability of this model to be used to ask more difficult and precise questions about metabolism of dairy cattle.

Milk protein yield was also described reasonably well by the model (Figures 3 and 6 ). The average milk protein yield predicted was $5.3 \%$ less than observed; again, this was likely a function of the error in setting the original parameters of the model to the cows' produc- 


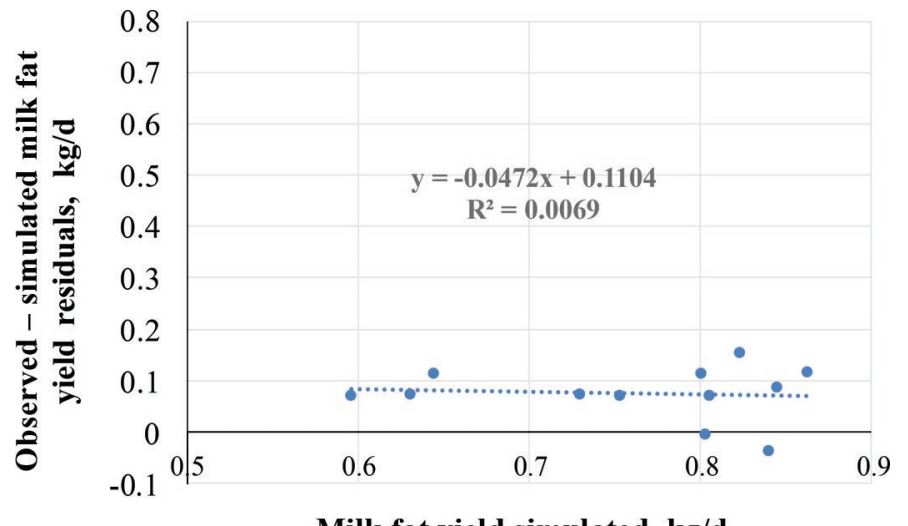

Milk fat yield simulated, $\mathrm{kg} / \mathrm{d}$

Figure 5. Regression comparison of simulated milk fat yield and the residuals of observed - simulated milk fat yield for $11 \mathrm{~d}$ of a short-term pasture supplementation study followed by an 11-d period of $6,8,10$, and $12 \mathrm{~kg}$ of that supplement per day. Control = pasture allowance plus a simple supplement; PMR1 = pasture allowance plus a mixed supplement; and PMR2 = pasture allowance plus a supplement balanced for protein and energy. The total bias in the root mean square prediction error was $0.075 \mathrm{~kg} / \mathrm{d}$ or $9.0 \%$ of the observed mean, and, of the total bias, the mean bias was $99.03 \%$, the line (slope) bias was $0.025 \%$, and the random bias was $0.94 \%$. Color version available online.

tion when the supplementation started. The total bias of the predictions was $0.0316 \mathrm{~kg} / \mathrm{d}$ or $5.3 \%$ of the mean and, of that, the mean bias was $99.74 \%$, the line bias was $0.221 \%$, and the random bias was $0.048 \%$. This suggests that the model was able to describe responses to increasing supplementation reasonably well.
The pattern of increasing total amount (moles) of VFA with supplementation was clearly demonstrated in the model (Figure 7; Auldist et al., 2013). The comparison of molar proportions of VFA in the rumen between simulated and observed (Figure 8) showed that, in general, the behavior the model represented the observations reasonably well (Figure 8; Gregorini et al., 2013; Hanigan et al., 2013). The predicted acetate molar percent was slightly higher than observed, predicted propionate was significantly higher, and predicted butyrate was significantly lower, but predicted values for acetate and propionate were within $1 \mathrm{SD}$ of observations and butyrate within 2 SD (Figure 8 ). The overall accuracy of the model predictions was affected by a very large discrepancy between the measured data and predicted value for propionate in PMR1 in the 12 $\mathrm{kg} / \mathrm{d}$ group. The observed value was far removed from any others in the study and difficult to explain biologically; it was likely due to some unknown condition of those cows at that time or some type of experimental error. The performance of the cows and of the model on all the other treatment and supplement combinations was as expected.

The analysis of bias for acetate was as follows: total bias $=4.0 \mathrm{~mol} \%$ (6.1\% of observed mean), partitioned as $67.5 \%$ mean bias, $8.2 \%$ line bias, and $24.3 \%$ random bias. For propionate, mean bias was $-1.8 \mathrm{~mol} \%(9 \%$ of the mean), primarily due to the large variation in PMR1 at $12 \mathrm{~kg} / \mathrm{d}$ (without that value, it was $-2.8 \mathrm{~mol}$ $\%$ ); and mean, line, and random bias were 20.2, 27.8,

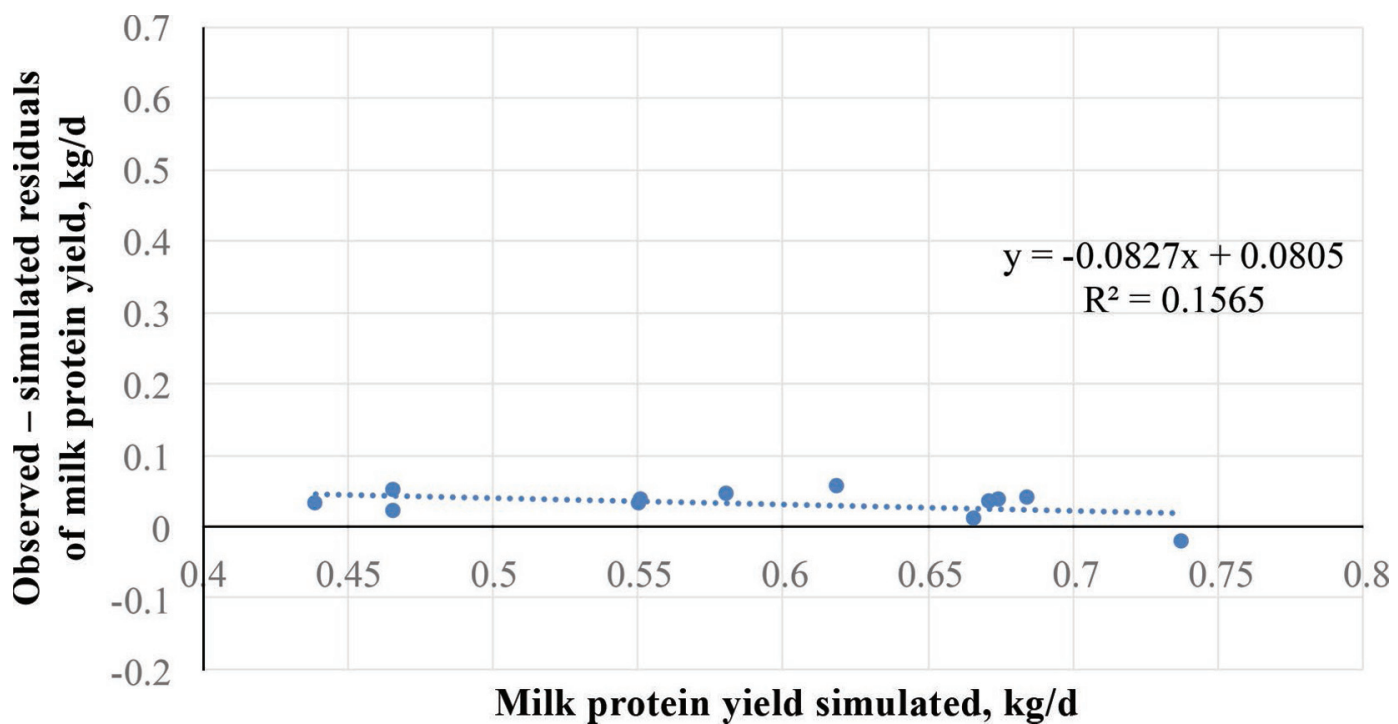

Figure 6. Regression comparison of simulated milk protein yield and residuals of observed - simulated milk protein yield in an 11-d pasture supplementation study. Animals were from 3 long-term supplementation treatments [Control = pasture allowance plus a simple supplement; PMR1 = pasture allowance plus a mixed supplement; and PMR2 = pasture allowance plus a supplement balanced for protein and energy], followed by an 11-d period of $6,8,10$, and $12 \mathrm{~kg}$ of that supplement per day. The total bias of the simulations was $0.0316 \mathrm{~kg} / \mathrm{d}$ or $5.3 \%$ of the mean, and of that, the mean bias was $99.74 \%$, the line bias was $0.221 \%$, and the random bias was $0.048 \%$. Color version available online. 
a)

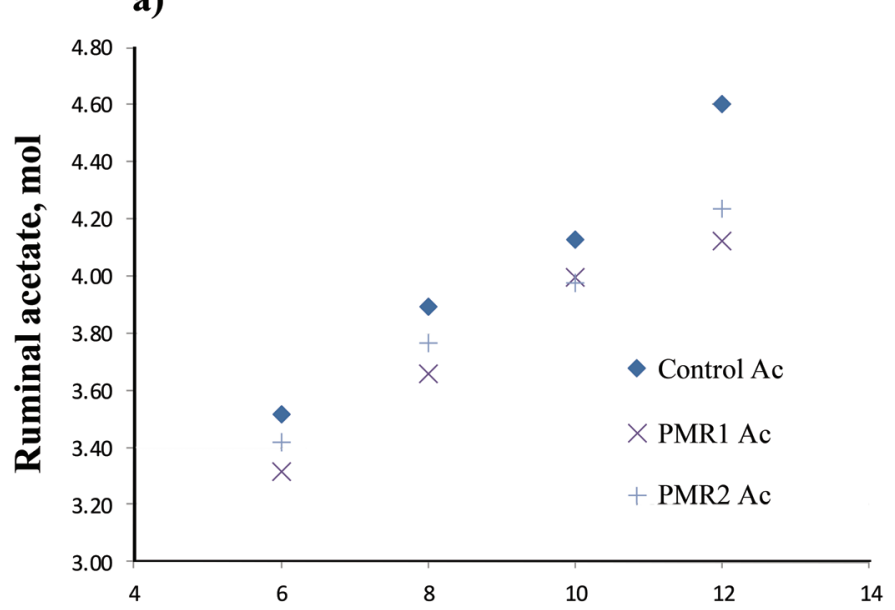

b)

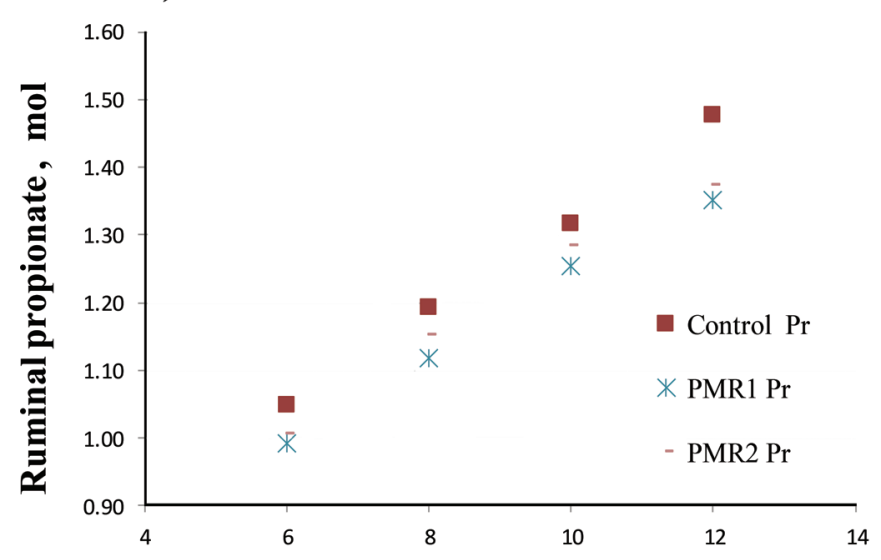

c)

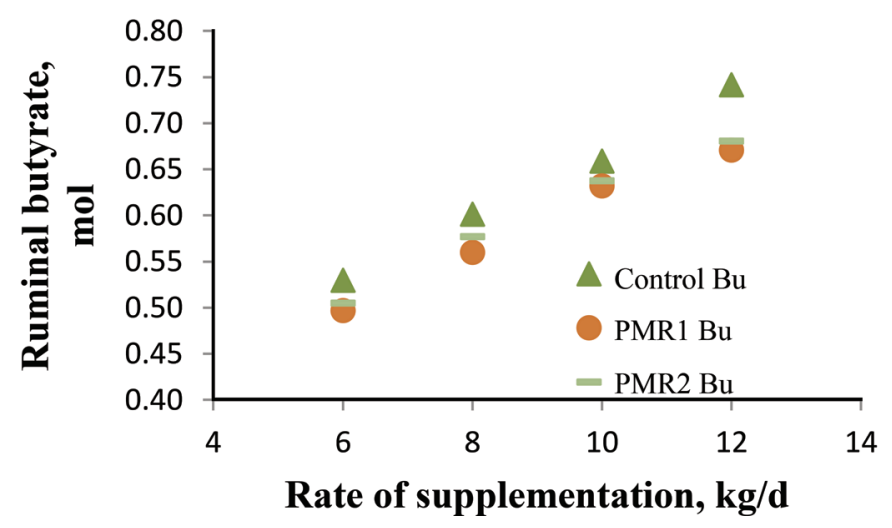

Figure 7. Simulated rumen total VFA amounts (mol) in an 11-d pasture supplementation study: (a) acetate (Ac); (b) propionate (Pr); and $(\mathrm{c})$ butyrate $(\mathrm{Bu})$. Animals were from 3 long-term supplementation treatments followed by an 11-d period of $6,8,10$, and $12 \mathrm{~kg}$ of that supplement per day. Control $=$ pasture allowance plus a simple supplement (quadratic fit); PMR1 (mixed) = pasture allowance plus a mixed supplement; and PMR2 (balanced) = pasture allowance plus a supplement balanced for protein and energy. Color version available online. and $52.0 \%$, respectively. Without the value for PMR2 at $12 \mathrm{~kg} / \mathrm{d}$, these values for mean, line, and random bias were $20.3,38.6$, and $21.4 \%$, respectively. For butyrate, total bias was $2.2 \mathrm{~mol} \%$ (20\% of the mean) and the partitioning was $76.2 \%$ mean bias, $8.3 \%$ line bias, and $15.5 \%$ random bias. In general, the low line bias indicates adequate model structure (slope of actual to predicted was close to 1), the high random bias indicates that most error was in the observed measures, but the high mean bias indicates a systemic lack of fit for actual mean prediction. Although we can describe the general trends of VFA production in response to diet, we do not yet quantitatively understand all the contributions to VFA production, metabolism, and uptake in the rumen.

One serious issue noted by most in the dairy nutrition field is that all of our models of VFA production are based on very few actual measurements of production. The present model has been updated twice for improved parameter values for fiber and starch digestion and for VFA uptake from the rumen. A more recent update since this version became available has improved the fit again to some extent (Ghimire et al., 2014). Given the performance in this very strict test of model ability to describe complex situations (i.e., that is 6, 9, and $20 \%$ error in mean Ac, Pr, and Bu mol \%), one interpretation is that the model clearly "fails." Yet looking at the graphical comparisons, the model does in fact work well. Although error of 6 to $20 \%$ may seem high, over $30 \mathrm{yr}$, we have not been able to improve our methodology to estimate complex rumen interactions. The predicted VFA values fell within 1 SD of actual observed values in most of these studies; therefore, improvements in techniques to measure rumen fluxes would improve precision of the model.

In this investigation, measured ruminal fluid $\mathrm{pH}$ decreased with level of grain supplementation and was negatively related to the measured concentration of total VFA, and, for the most part, the predicted $\mathrm{pH}$ values and predicted concentrations of VFA in ruminal fluid matched the observed values. Ruminal fluid $\mathrm{pH}$ is difficult to measure well; however, this study monitored $\mathrm{pH}$ in detail over time and it is likely that accurate measures were obtained. The role of $\mathrm{pH}$ in the model is known to be inadequate, especially on very high grain diets and, certainly, this function of the model needs to be improved with better data. Presently in the model, $\mathrm{pH}$ is calculated as a direct function of total VFA concentration. Changing $\mathrm{pH}$ does not affect the rumen model production of VFA above a value of 6.2. The $\mathrm{pH}$ value between 6.2 and 5.4 is then used to adjust the production of VFA from starch and soluble carbohydrate; such that as $\mathrm{pH}$ decreases, the amounts (or production rates) of acetate, propionate, and butyrate 


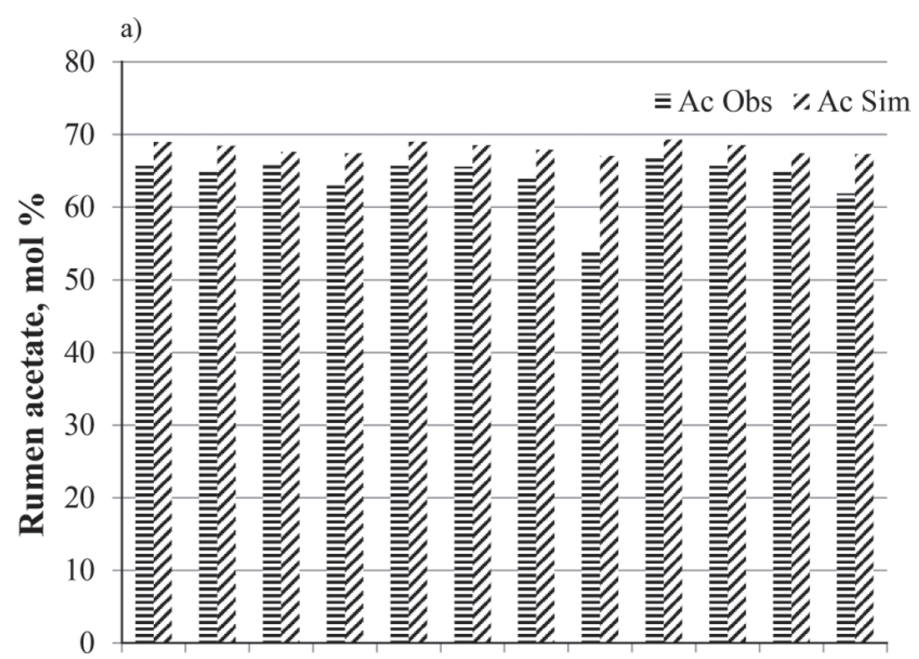

C6 C8 C10 C12 M6 M8 M10 M12 B6 B8 B10 B12
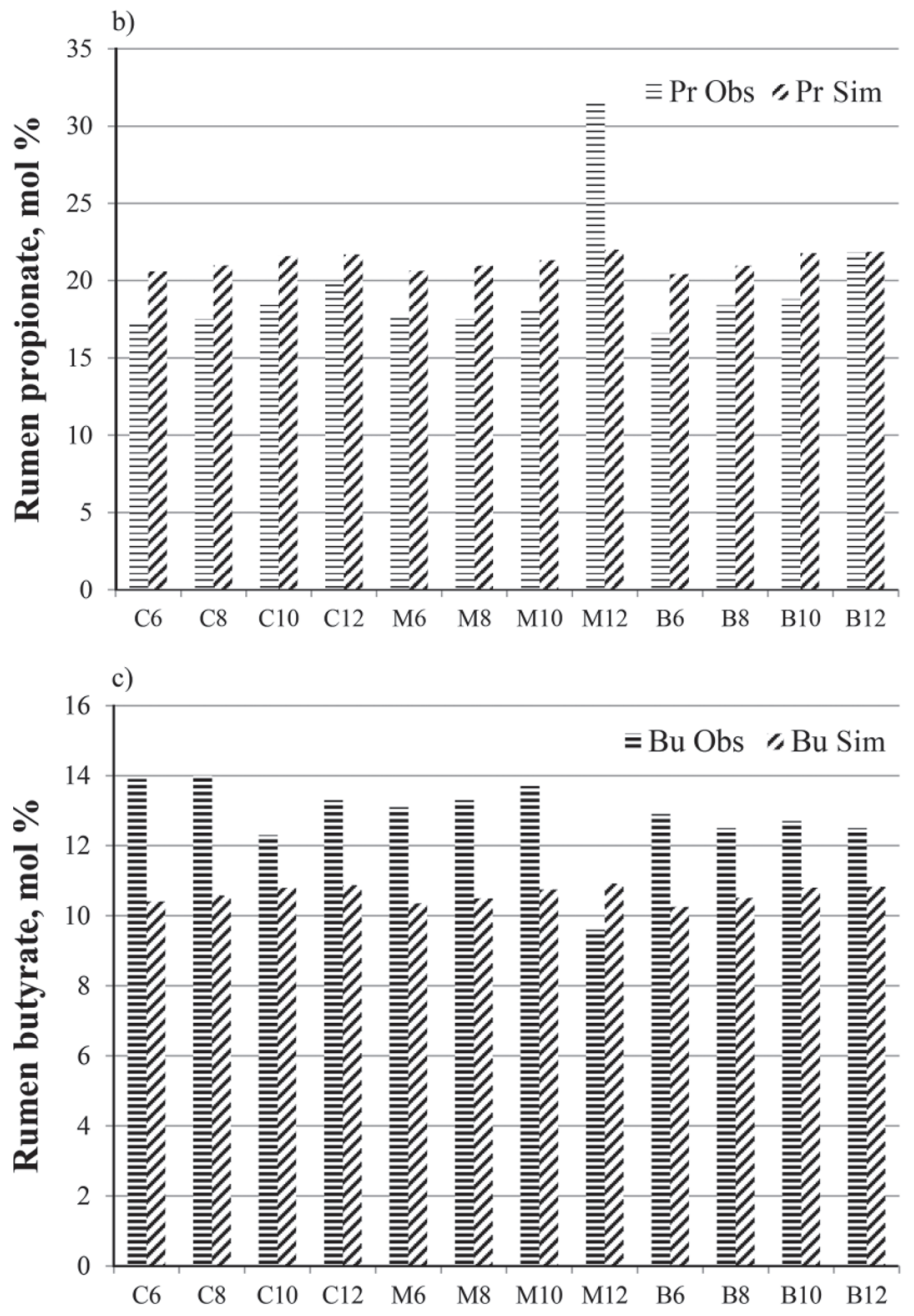

Supplemental treatment

Figure 8. Simulated (Sim) and observed (Obs) rumen VFA molar percentages for an 11-d pasture supplementation study: (a) acetate (Ac); (b) propionate $(\mathrm{Pr})$; and $(\mathrm{c})$ butyrate $(\mathrm{Bu})$. Animals were from 3 long-term supplementation treatments followed by an 11-d period of 6, 8, 10, and $12 \mathrm{~kg}$ of that supplement per day. Control $(\mathrm{C})=$ pasture allowance plus a simple supplement; PMR1 $(\mathrm{M})=$ pasture allowance plus a mixed supplement; and PMR2 (B) = pasture allowance plus a supplement balanced for protein and energy. 
decrease and the production rate of lactate increases. As stated by Baldwin (1995), this is likely incorrect, but since that time, few attempts have been made to obtain newer estimates of VFA production and rumen $\mathrm{pH}$ over a wide enough range to improve the equations, although one suggested alternative provided smoother curves for effects of $\mathrm{pH}$ on VFA production (Ellis et al., 2008, 2009; Bannink et al., 2008). These new equations have not yet been incorporated into the model and tested. It is expected that the data from the current experiment will be used to provide better function of the rumen model.

The model predicted that ruminal fluid $\mathrm{pH}$ was approximately $0.2 \mathrm{pH}$ units lower than measured values, and although the $\mathrm{pH}$ did decrease with increasing VFA concentrations due to supplementation (Figure 9), the effect was small. This was clearly reflected in the partitioning of prediction bias such that mean bias was $94.6 \%$ of the total bias, and line and random bias were 1.8 and $3.9 \%$ respectively. Clearly, the original model is not robust in describing $\mathrm{pH}$ changes, which is not surprising as there were not sufficient data to do so at the time the model was first developed. Recent analyses of newer data have suggested additional adjustments to $\mathrm{pH}$ (e.g., adjusting VFA stoichiometry in a sigmoidal fashion with decreasing $\mathrm{pH}$, account for $\mathrm{pH}$ effects of other acids; Nagorcka et al., 2000; Ellis et al., 2008, 2009; Bannink et al., 2008).

\section{CONCLUSIONS}

A mechanistic, dynamic model of digestion and metabolism in the dairy cow was used to ask direct questions about our ability to describe complex ruminal and metabolic interactions. The model was able to describe changes in digestion, VFA production, and milk component outputs from cattle on a 12-diet combination of treatments. The current research has shown that model is robust in the ability to describe complex feeding strategies, yet needs improvement in the way it describes VFA concentrations and ruminal fluid $\mathrm{pH}$. The underlying structure of the model provides explanatory power from this pasture supplementation study. However, improvements in the model parameters describing substrate digestion, VFA production, and resultant milk composition are needed.

\section{ACKNOWLEDGMENTS}

This study was conducted as part of the Productive Dairy Feeding Systems project, a joint project between Department of Primary Industries (Ellinbank, Victoria, Australia) and Dairy Australia (Ellinbank, Victoria, Australia). This study was conducted as part of the
US Regional Research Project NC 1040: Metabolic relationships in supply of nutrients for lactating cows (UDSA NIFA, Washington, DC).
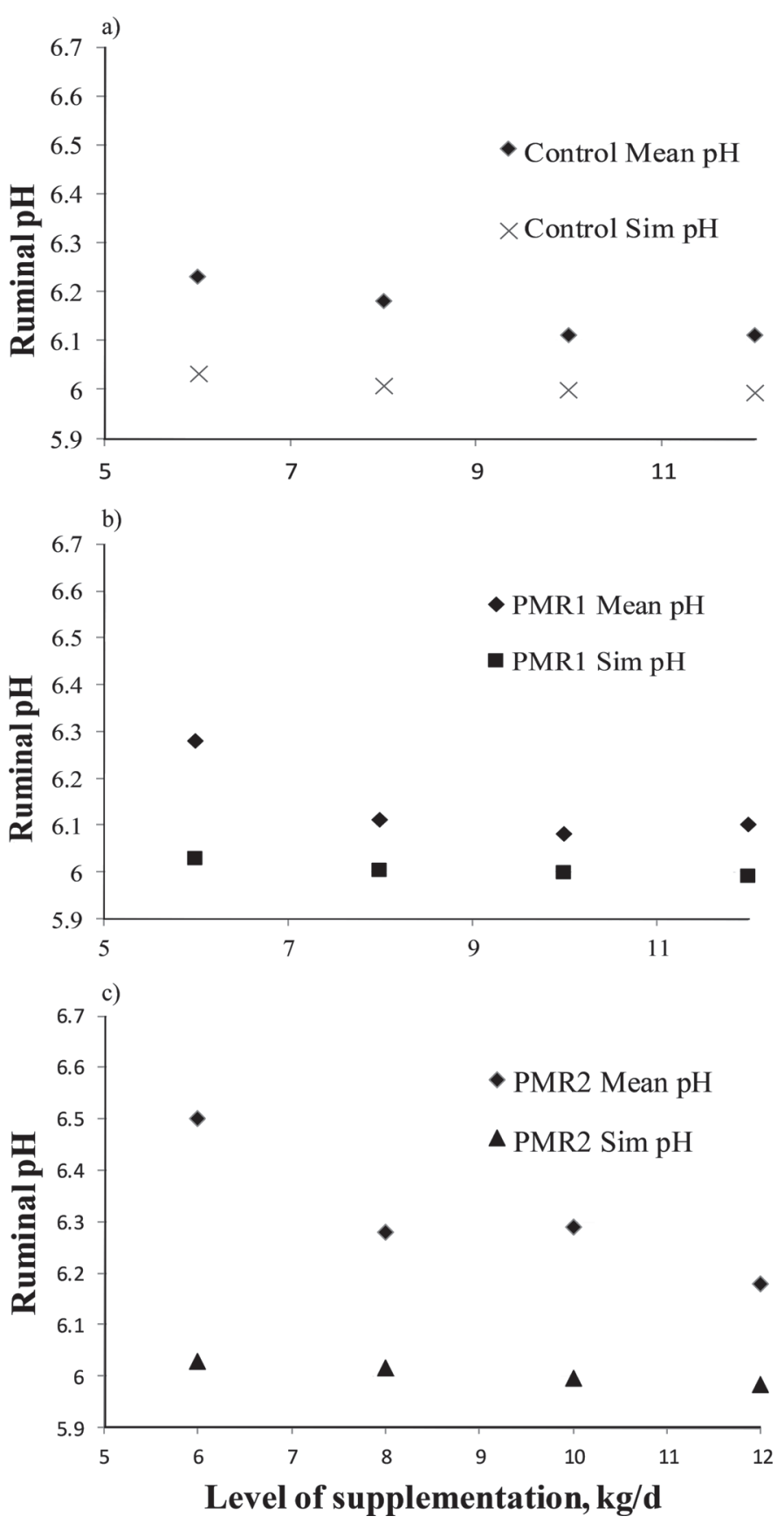

Figure 9. Simulated ( $\mathrm{Sim}$ ) and observed rumen $\mathrm{pH}$ in an 11-d pasture supplementation study. Animals were from 3 long-term supplementation treatments followed by an 11-d period of $6,8,10$, and 12 $\mathrm{kg}$ of that supplement per day. (a) Control = pasture allowance plus a simple supplement; (b) PMR1 (mixed) = pasture allowance plus a mixed supplement; and (c) PMR2 (balanced) = pasture allowance plus a supplement balanced for protein and energy. 


\section{REFERENCES}

Auldist, M. J., L. C. Marett, J. S. Greenwood, M. Hannah, J. L. Jacobs, and W. J. Wales. 2013. Effects of different strategies for feeding supplements on milk production responses in cows grazing a restricted pasture allowance. J. Dairy Sci. 96:1218-1231.

Baldwin, R. L. 1995. Modeling Ruminant Digestion and Metabolism. Chapman and Hall, London, UK.

Baldwin, R. L., J. France, D. E. Beever, M. Gill, and J. H. Thornley. 1987a. Metabolism of the lactating cow. III. Properties of mechanistic models suitable for evaluation of energetic relationships and factors involved in the partition of nutrients. J. Dairy Res. 54:133-145.

Baldwin, R. L., J. France, and M. Gill. 1987b. Metabolism of the lactating cow. I. Animal elements of a mechanistic model. J. Dairy Res. 54:77-105.

Baldwin, R. L., J. H. Thornley, and D. E. Beever. 1987c. Metabolism of the lactating cow. II. Digestive elements of a mechanistic model. J. Dairy Res. 54:107-131.

Bannink, A., J. France, S. Lopez, W. J. J. Gerrits, E. Kebreab, S. Tamminga, and J. Dijkstra. 2008. Modelling the implications of feeding strategy on rumen fermentation and functioning of the rumen wall. Anim. Feed Sci. Technol. 143:3-26.

Beever, D. E., and P. T. Doyle. 2007. Feed conversion efficiency as a key determinant of dairy herd performance: A review. Aust. J. Exp. Agric. 47:645-657.

Ellis, J. L., J. Dijkstra, E. Kebreab, A. Bannink, N. E. Odongo, B. W. McBride, and J. France. 2008. Aspects of rumen microbiology central to mechanistic modelling of methane production in cattle. J. Agric. Sci. 146:213-233.

Ghimire, S., P. Gregorini, and M. D. Hanigan. 2014. Evaluation of predictions of volatile fatty acid production rates by the Molly cow model. J. Dairy Sci. 97:354-362.

Gregorini, P., P. C. Beukes, M. D. Hanigan, G. Waghorn, S. Muetzel, and J. P. McNamara. 2013. Comparison of updates to the Molly cow model to predict methane production from dairy cows fed pasture. J. Dairy Sci. 96:5046-5052.

Gregorini, P., J. Galli, A. J. Romera, G. Levy, K. A. McDonald, H H. Fernandez, and P. C. Beukes. 2014. Incorporating a prediction of postgrazing herbage mass into a whole-farm model for pasturebased dairy systems. J. Dairy Sci. 97:4354-4366.

Hanigan, M. D., J. A. Appuhamy, and P. Gregorini. 2013. Revised digestive parameter estimates for the Molly cow model. J. Dairy Sci. 96:3867-3885.

Hanigan, M. D., H. G. Bateman, J. G. Fadel, J. P. McNamara, and N. E. Smith. 2006. An ingredient-based input scheme for Molly. Pages 328-348 in Nutrient Digestion and Utilization in Farm Animals: A Modelling Approach. E. Kebreab, J. Dijkstra, A. Bannink, W. Gerrits, and J. France, ed. CAB International, Wallingford, UK.

Hanigan, M. D., C. C. Palliser, and P. Gregorini. 2009. Altering the representation of hormones and adding consideration of gestation- al metabolism in a metabolic cow model reduced prediction errors J. Dairy Sci. 92:5043-5056.

Hanigan, M. D., A. G. Rius, E. S. Kolver, and C. C. Palliser. 2007. A redefinition of the representation of mammary cells and eAUSyme activities in a lactating dairy cow model. J. Dairy Sci. 90:38163830.

Leddin, C. M., C. R. Stockdale, J. Hill, J. W. Heard, and P. T. Doyle. 2009. Increasing amounts of crushed wheat fed with pasture hay reduced dietary fiber digestibility in lactating dairy cows. J. Dairy Sci. 92:2747-2757.

McNamara, J. P. 2015. Systems biology of regulatory mechanisms of nutrient metabolism in lactation. J. Anim. Sci. 93:5575-5585.

McNamara, J. P., and R. L. Baldwin. 2000. Estimation of parameters describing lipid metabolism in lactation: Challenge of existing knowledge described in a model of metabolism. J. Dairy Sci 83:128-143.

McNamara, J. P., and S. L. Shields. 2013. Reproduction during lactation of dairy cattle: Integrating nutritional aspects of reproductive control in a systems research approach. Anim. Front. 3:76-83.

Mould, F. L., E. R. Orskov, and S. O. Mann. 1983. Associative effects of mixed feeds. I. Effects of type and level of supplementation and the influence of the rumen fluid $\mathrm{pH}$ on cellulolysis in vivo and dry matter digestion of various roughages. Anim. Feed Sci. Technol. 10:15-30.

Murphy, M. R., R. L. Baldwin, and L. J. Koong. 1982. Estimation of stoichiometric parameters for rumen fermentation of roughage and concentrate diets. J. Anim. Sci. 55:411-421.

Nagorcka, B. N., G. L. R. Gordon, and R. A. Dynes. 2000. Towards a more accurate representation of fermentation in mathematical models of the rumen. Pages 37-48 in Modelling Nutrient Utilization in fFarm Animals. Proc. 5th Int. Workshop on Modeling Nutrient Utilization in Farm Animals. J. P. McNamara, J. France, and D. Beever, ed. CAB International, Wallingford, UK.

Roseler, D. K., D. G. Fox, A. H. Pell, and L. E. Chase. 1997. Evaluation of alternative equations for prediction of intake in Holstein dairy cows. J. Dairy Sci. 80:864-877.

Stockdale, C. R. 2000. Levels of pasture substitution when concentrates are fed to grazing cows in northern Victoria. Aust. J. Exp. Agric. 40:913-921.

Stockdale, C. R., A. Callaghan, and T. E. Trigg. 1987. Feeding high energy supplements to pasture-fed dairy cows, effects of stage of lactation and level of supplement. Aust. J. Agric. Res. 38:927-940.

Wales, W. J., and P. T. Doyle. 2003. Effect of grain and straw supplementation on marginal milk production responses and rumen function of cows grazing highly digestible subterranean clover pasture. Aust. J. Exp. Agric. 43:467-474.

Walker, G. P., C. R. Stockdale, W. J. Wales, P. T. Doyle, and D. W. Dellow. 2001. Effect of level of grain supplementation on milk production responses of dairy cows in mid-late lactation when grazing irrigated pastures high in paspalum (Paspalum dilatatum Poir.). Aust. J. Exp. Agric. 41:1-11. 